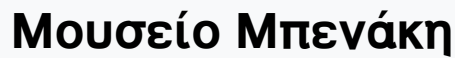

A Singular Antiquity: Archaeology and Hellenic Identity in Twentieth-Century Greece

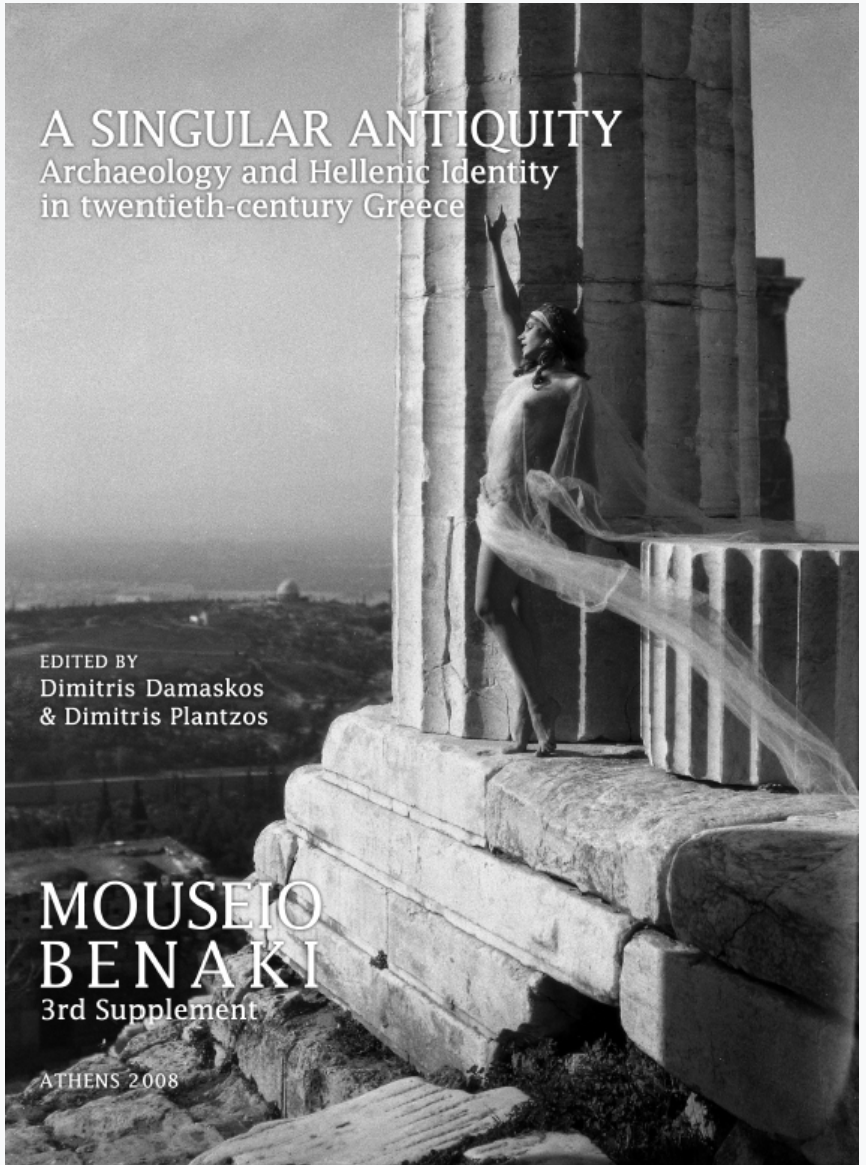

\section{Archaeology and Greekness on the centenary} celebrations of the Greek state

Dora F. Markatou

doi: $10.12681 /$ benaki.18057

\section{Copyright ( ) 2018, Dora F. Markatou}

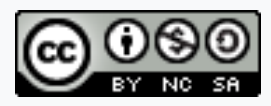

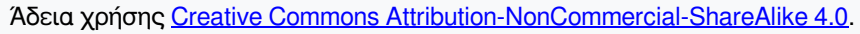

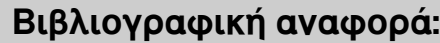

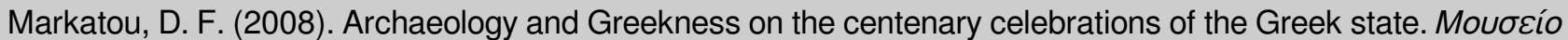
Мпєvákn, 309-320. https://doi.org/10.12681/benaki.18057 


\section{Archaeology and Greekness on the centenary celebrations of the Greek state}

ON 31 July 1829, the eighth decree of the Fourth National Assembly at Argos, convened by Ioannis Kapodistrias, brought up for the first time the issue of formal expression of gratitude of those who had contributed to the independence of the Greek nation, by erecting, in due time, the Church of our Saviour as a panhellenic memorial, and other monuments. ${ }^{1}$ Thus, Kapodistrias officially became both the father of the modern Greek war memorial and the instigator of manifestations of national gratitude, which would later become an important obligation of the Greek State. At the same time, a framework was set, for fulfilling some 'promises' to the brothers-in-arms who - for their homeland's sake - had sacrificed themselves, such as the promise made by Alexandros Hypsilantis to the Sacred Band ('Ieros Lochos') after the battle of Dragatsanion with the words: 'The time is near when your names shall be perpetuated'. ${ }^{2}$ However, discussions concerning these 'Shrines of Eternity' and 'Prizes of Honour and Glory's lasted for more than a century. The well-known historian Spyridon Lambros (1851-1919) contributed a great deal to furthering the discussion begun by Kapodistrias.

In particular, from 1891 until at least 1916 every year on 25 March, Spyridon Lambros had been announcing the celebratory character of the day, stressing the need to show the nation's gratitude to the heroes of 1821. In 1899, he first expressed the opinion that the nation should erect a national war memorial dedicated to the War of Independence: 'It is the nation's duty to immortalize the memory of great heroes' ${ }^{\prime 4}$ and he began dreaming of a magnificent commemoration before this monument: 'There my imagination loves to wander and watch the festive procession celebrating the Liberation'.5 In subsequent years, in addresses of the national day he delivered at the University, at the Zappeion Hall, at the Parnassus Philological Society and other places, he would repeat his suggestion. On 25 March 1909 he addressed his fellow countrymen at Cairo's Hellenic Centre saying: 'Very few years remain until 1921 comes around. [...] Let all of us think [...] from now on, that we should contribute to honouring our heroes of 1821 on the Centenary of our national war of independence'. ${ }^{6}$

During the Balkan Wars such proposals were much debated whereas the victorious outcome led to an association between the epic struggle of 1821 and that of 1912-1913, making the need to find a way of expressing the nation's gratitude to those who had contributed to the nation's triumphs much more pressing.

In 1916, when Spyridon Lambros was Minister of Education, he began the process of forming a committee to prepare a commemoration. Unfortunately, owing to the political upheaval of the time, the project foundered.

In 1918, the Greek Parliament enacted Law 1375, according to which 1921 was established as the official year of the centenary celebrations for the Greek Revolution. The Venizelos government formed a Central Committee for the Centenary Commemoration of the Greek Revolution (henceforth CCC), which was replaced by another committee in 1921 after Venizelos' electoral defeat in 1920. However, the new committee was forced to postpone the event until 1930 owing to the Asia Minor campaign. Thus, in 1928 the Venizelos government formed another committee which, eventually, organized the centenary commemoration. ${ }^{7}$ 
According to Lambros' stipulations, the aim of the commemoration was on the one hand to express gratitude to those who had taken part in the effort for 'national restoration', and on the other to highlight the progress that had been made in the last one hundred years in all aspects of Greece's public and civil life; or - according to Konstantinos Amantos - to 'take stock of the achievements during those one hundred years. ${ }^{8}$ This last ambition would to a great extent, though not exclusively, define the content of the celebration. Everything had to be Greek, created by Greeks, and inspired by Greek history. As writers on the subject used to put it, everything had to be 'national'.

Georgios Haritakis, general secretary of the 1921 CCC, summed this up when he said: 'In carrying out our programme, we should have recourse exclusively to our national powers and abilities so that it retains its purely national character.'

I must make it clear at this point that I have used the term 'Greekness', though it is not found in documents relating to the Centenary, in order to indicate by this now common term the exclusively Greek character of the celebrations their organizers were aiming for. ${ }^{10}$

Furthermore, the CCC appointed special committees to take care of specific aspects of the Panhellenic Commemoration. The members of these committees were representative of the whole range of the country's public life, including scientists and academics. Among the academics there were understandably a number of archaeologists given that the newly established state linked the formation of its 'national present' so closely with the past ${ }^{11}$ in general and more especially with antiquity. ${ }^{12}$ Spyridon Lambros considered antiquity fundamental for the restoration of the nation. To be more specific, in his annual oration on 25 March 1905, he stressed: 'Modern Greece was liberated not only by the heroism and self-sacrifice of modern Greeks. Ancient Greece also contributed to her freedom. On the same day, the First International Conference of Archaeology began in Athens and Spyridon Lambros associated this event with the celebrations in honour of Greece's independence: 'In the Festival of Liberty that we are celebrating this year there is a triple celebration: a commemoration of the heroes and martyrs of 1821, a festival of thanksgiving for the greatness of Ancient Greece, to which in large part we owe our revival, and an acknowledgement of gratitude to the fellow citizens and descendants of the Philhellenes, ${ }^{13}$ who were brought to love Modern Greece through their admiration for Ancient Greece [...].'. ${ }^{14}$

Among the archaeologists who sat on the special committees mention should be made of: Christos Tsountas, designated chairman of the Committee for the 'representation of the various eras in the life of the Greek nation' in 1918 and appointed member of the Committee on publications, and of the subcommittees for commemorative albums and archaeology in 1921; Georgios Sotiriou, appointed member of the Committee for designating places of historical interest in 1918, member of the Committee on publications, and of the subcommittees for commemorative albums and archaeology in 1921, and member of the Committee for national museums and the Herod Atticus Theatre in 1929; Anastasios Orlandos, appointed vicechairman of the Committee for monuments and member of the subcommittee for the visual arts in 1921, and member of the Committee for the war memorial in 1929.15

Other distinguished archaeologists, such as Panayiotis Kavadias, Ioannis Svoronos, Konstantinos Kourouniotis, Georgios Oikonomos, Alexandros Philadelpheus, and Adamantios Adamantiou, to mention only the best known, sat at least once on such committees. Moreover, a place was always reserved for the Ephor of Antiquities in Attica. Archaeologists serving in regional ephorates were usually members of local committees, as was for example Spyridon Marinatos, who was appointed committee member in Herakleion. If we add the archaeologists who were appointed to committees for judging submissions to competitions for the design of various memorials, and university professors from related disciplines, e.g. Sokratis Kougeas, Andreas Skias, Georgios Chatzidakis, Pavlos Karolidis and Grigorios Vernardakis, it is clear that these academics steeped in antiquity played a decisive role in deciding just what the spirit and the form of the celebrations should be as well as influencing the decisions taken with regard to the monuments being commissioned at the time.

I should point out, however, that it was very easy for them to promote their views, since Ioannis Damvergis, a very well-known man of letters, poet, journalist and a close associate of Venizelos since the time of the Balkan Wars, was General Secretary of the CCC during that period. He was, indeed, at the very heart of the CCC, which was responsible for organizing the programme and also gave general guidelines for the organization of regional programmes. He was extremely conservative, a lover of 
antiquity and of Byzantium and a proponent of the 'Great Idea'. Moreover, he was an admirer of the man who had inspired the centenary celebrations, Spyridon Lambros. In other words, he believed in the unbroken continuity of the Greek race; in the connection of modern Greece with ancient Greece, with Byzantium as the essential intermediary; in the moral and educational value of art and especially of the public monument in accordance with ideas formed in Europe after the French Revolution. ${ }^{16}$

The effect of Lambros' beliefs on the celebration's organizers was such, that in studying what was written in those days, one has the impression that all of them were simply paraphrasing his words. Even Georgios Haritakis, a professor at the Athens School of Economics (ASOE), General Secretary of the CCC in 1921, an important figure in the inter-war period, and a man whose programme proved even more demanding than that of Damvergis, is echoing the words of Lambros when he says: 'Those memorials [...] will definitely serve the purpose of setting an example for the generations to come and educate them in such a way that they not only hear about their ancestors' achievements but also see them.' ${ }^{17}$

Forty years earlier, in 1881, Spyridon Lambros had noted that 'To make History come to life [...] it should be, as it were, both visible and audible. Besides school classes and teaching from books, the fine arts are able to contribute to this. ${ }^{18}$

Sotiris Skipis is even clearer: 'If the most important events of our national struggle had been sculpted in marble, Athens would have become one vast school for heroic tuition and upbringing..$^{19}$ It is obvious that for the commemoration organizers and for those involved in public discourse, expressing gratitude by erecting memorials was a combination of 'honouring and teaching' ${ }^{20}$ in accordance with the European example.

Spyridon Lambros was not the only one who accepted the notion prevailing in Europe since the nineteenth century that archaeology was above all a national discipline. At the First National Archaeological Conference he stressed: 'For you, who are foreigners, your love of Antiquity and the study of it are both a scientific necessity and a vital joy; for us Greeks, however, it is also a patriotic duty'. ${ }^{21}$

According to these views, by serving a national discipline the archaeologists were able to guarantee the objective of the CCC: to ensure the national character of the commemorations, or in modern parlance their 'Greekness'.
Only by keeping in mind Lambros' views is it possible to follow the rhetoric of the organizers; to understand the rationale behind the composition of certain committees such as the Committee for national museums and the Herod Atticus Theatre and the Committee for the representation of the various eras in the life of the Greek nation; to grasp the form, the content and the ideological function of some celebrations such as the Flag Ceremony, which I shall refer to below and, overall, to understand the inclusion in the programme of events linking antiquity and its monuments with recent history. For instance, the official completion of restoration works on the Acropolis was included in the Centenary programme, as was a speech by the civil engineer in charge, Nikolaos Balanos, on 'The Restored Monuments of the Acropolis (1834-1930).'.22 Both symbolize the reborn or, as it were, 'restored' nation which, after its own restoration, was keen to show off its restoration work, something it considered a duty it owed to the past.

In the same spirit, much effort was made to restore the Herod Atticus Theatre and to find suitable premises for the Byzantine Museum and the Museum of the Historical and Ethnological Society. Archaeological sites and monuments were used for ancient drama or dance performances, inspired by Greek mythology, antiquity or even ancient Greek music. Tanagra and Vassos Kanellos (fig. 1) were a typical example: they presented the ballet Demeter and Persephone at Eleusis with an introductory speech by Alexandros Philadelpheus. Kourouniotis was their advisor on costumes and choreography. ${ }^{23}$ Examining the proceedings of the special committees, one realizes that the archaeologists among their members backed Damvergis' suggestions for archaizing performances such as the recreation of the Panathenaic procession or a Byzantine triumph. ${ }^{24}$

In other words, the archaeologists were not the ones who introduced those demonstrations all' antica, but they underwrote them. They were Damvergis' allies, so to speak, and thus stood warranty for the implementation of the programme which the CCC, most of whose members were politicians, wanted.

According to those who inspired it, the Flag Ceremony, held on 27 April 1930, was an exact re-enactment of the Panathenaic procession, adapted, of course, to suit the modern Christian era. This idea, too, was down to Damvergis; instead of Athena's peplos the procession would carry the Greek flag, which - just like the peplos - would be changed at the Acropolis every year, and each year a 

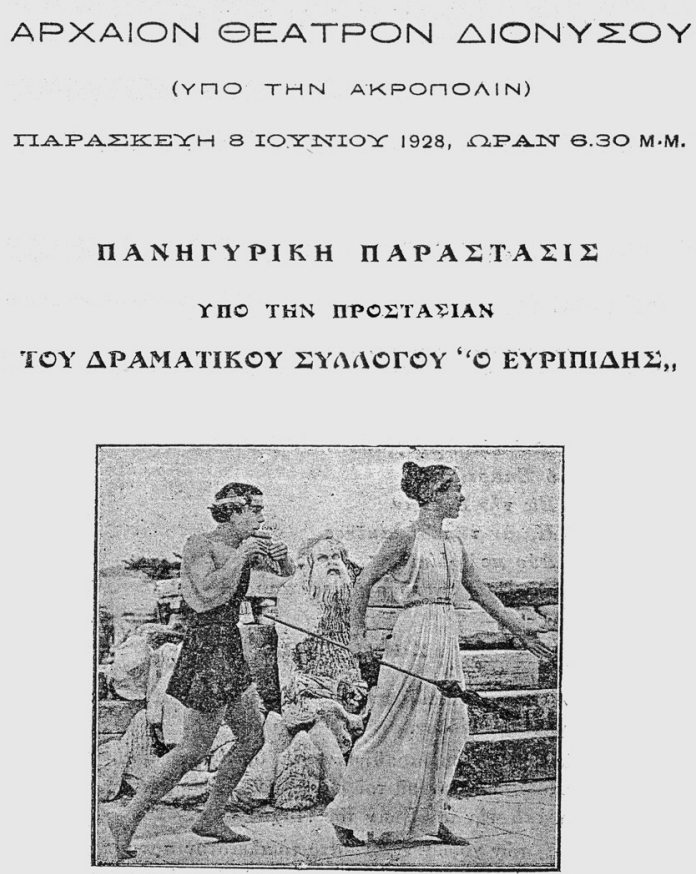

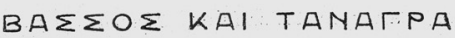

$$
\begin{gathered}
\text { KANEA N } \mathrm{NOY} \\
\text { KAA } \Sigma \Sigma I K \Omega N \text { XOPAN }
\end{gathered}
$$

Fig. 1. The programme of a dance performance by Tanagra and Vassos Kanellos.

different town or region would assume responsibility of the ceremony.

Angeliki Hatzimihali, member of the Committee for the representation of the various eras in the life of the Greek nation, expressed the opinion that 'the parade of the flag must be accompanied by representations of the three eras: the ancient Greek, the medieval and the modern'. ${ }^{25}$ It should be remembered that it was through the work of this eminent folklorist that Greek folk art, one of the basic sources of inspiration for the members of the generation of the thirties, was made known. And it was this group of artists who were most insistent about the need for 'Greekness' in art.

Naturally, Hatzimihali's suggestion was acted upon. According to extant descriptions, the procession consisted of eighteen groups. ${ }^{26}$ The first one included trumpeters and

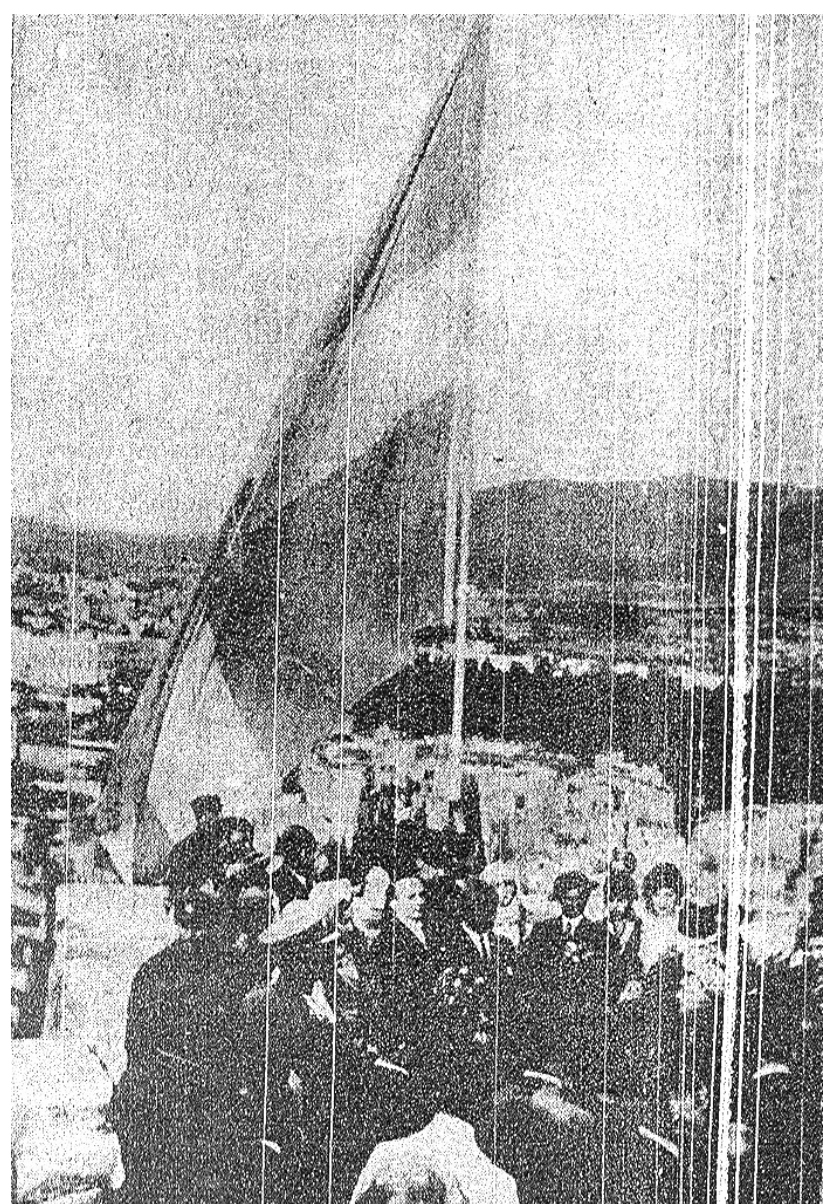

Fig. 2. Raising the Flag on the Acropolis (source: Estia, 28 May 1930).

evzones (members of the elite, fustanella-clad ceremonial unit of the Greek infantry), the second referred to Greek antiquity, the third to the Byzantine era, and the fourth to the War of Independence of 1821. The fifth was the group surrounding the flag: he huge flag was at the centre of the group, held alternately by the commanding officers of the reserve and its non-commissioned officers. Three ranks of soldiers and two of sailors marching five abreast, all armed with fixed bayonets went ahead of it. Four rows each made of four women in local costumes formed a square around the flag and, finally, the group ended with two more ranks of soldiers and sailors, again marching five abreast with fixed bayonets. The remaining groups consisted of representatives of the clergy, military officers and women's groups from all over Greece and Asia Minor (fig. 2). 


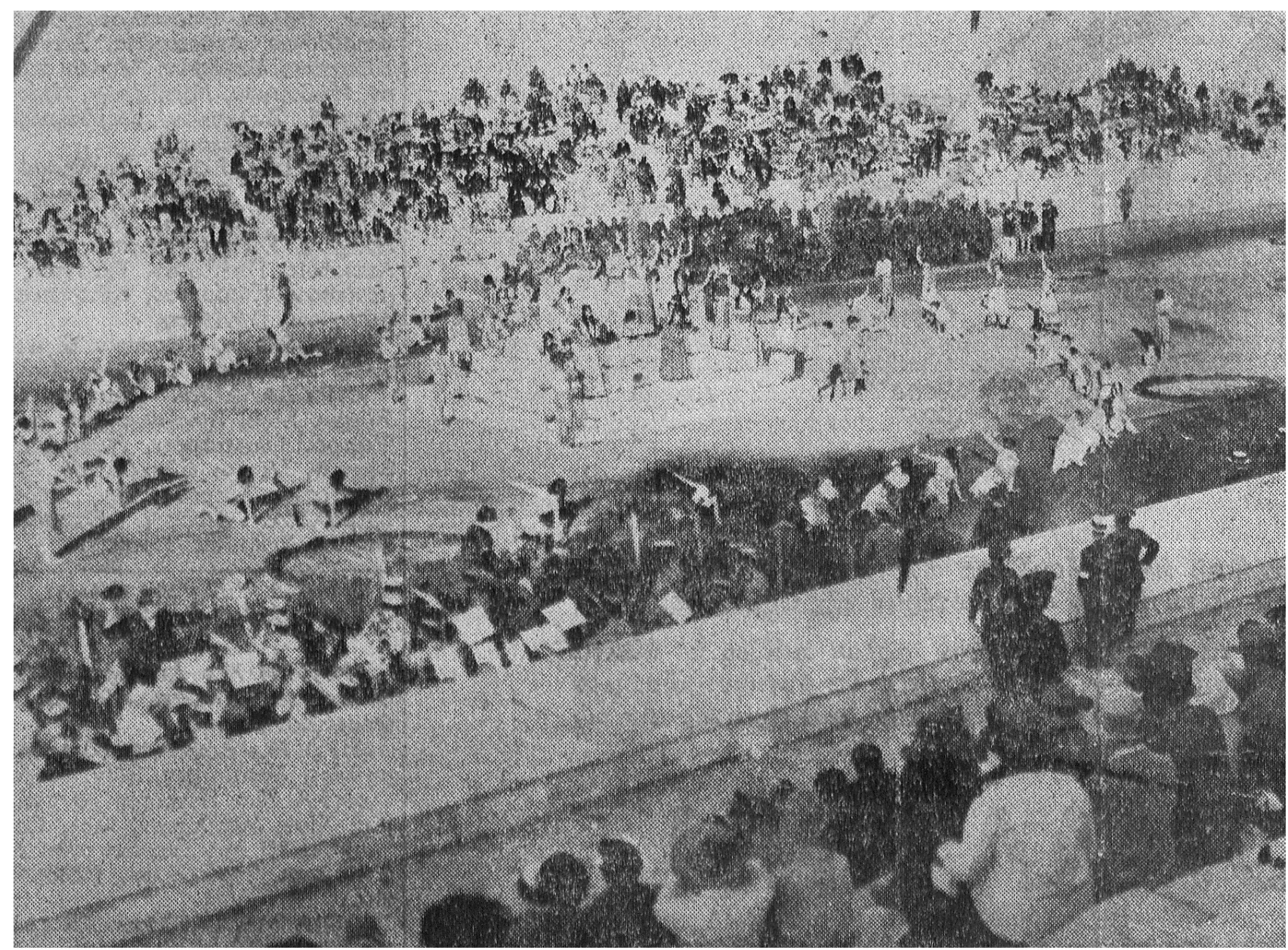

Fig. 3. 'Bloodless sacrifice from the Minoan Period' (source: Eleftheron Vima, 20 May 1929).

From the elements chosen to represent the flow of Greek history I mention the two rows of five 'Minoan maidens', which shows the way that prehistoric Crete was being subscribed to Greek history. Another example where the Minoan period was taking a prominent position was a celebration that had taken place the year before, when the Lyceum of Greek Women had organized an event in the Panathenaic Stadium. We can find out more about that celebration from the newspaper Eleftheron Vima: 'The celebration started with a religious procession and a bloodless sacrifice from the Minoan period. The reconstruction of the festival was based on murals from the Aegean Civilisation. The costumes were exact replicas of those in the murals and figurines discovered at Knossos, Phaestos, Tiryns and the Kadmeia. ${ }^{27}$ The caption on a photo depicting the performance by the Lyceum of Greek
Women (fig. 3), also published in the same paper, reads: 'The bloodless sacrifice during the Minoan era. By the altar stand priestesses, girls playing the kithara and cupbearers; around the altar are grouped the maidens who make up the procession artistically poised'.

The inclusion of the Minoan civilisation in ancient Greece and in the celebrations must have been Damvergis' idea. A Cretan himself he never missed an opportunity to promote the idea of Minoan culture being a forerunner to Classical Greece. We already know that in 1910 he had suggested that something called the 'Cretan leap' should be included in the Panhellenic games. ${ }^{128}$ Moreover, it was he who recommended the lighting of the Olympic Flame in Greece long before the Grand Duke of Mecklenburg to whom the suggestion is now attributed. ${ }^{29}$ Although the Byzantine 'triumphal' march did not actually take place, characteristic 


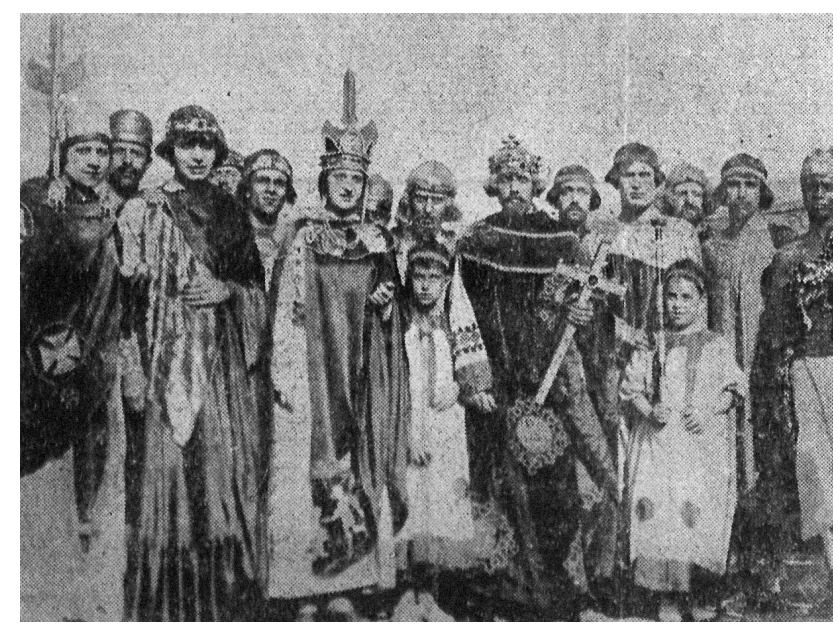

Fig. 4. 'Emperor Theophilos holding a cross in his hand and the Empress of Byzantium' (source: Eleftheron Vima, 20 May 1929).

images of the Byzantine period were published, such as the one presented in the celebration organized by the Lyceum of Greek Women with 'Emperor Theophilos' and the 'Empress of Byzantium’ (fig. 4).

The organizers paid special attention to the Celebration of the Flag and, judging by the way the event became established, they were right to do so. They had no experience of what they called 'urban' festivals. Therefore, they began by looking for models in Europe, but then, apparently for fear that this might detract from the national character they were pursuing to evoke, they turned to the well-known director Panos Aravantinos, then living in Berlin, to find an artistic director. ${ }^{30}$ In 1918 he had also been a member of the Committee for the panhellenic war memorial. ${ }^{31}$ Aravantinos politely refused. ${ }^{32}$ Besides the folklorist and painter Angeliki Hatzimihali mentioned above, members of the Representations Committee also included the artists K. Yeraniotis, Thomas Thomopoulos, Fokion Rok, E. Ioannidis, Odysseus Fokas and Georgios Bonanos. ${ }^{33}$ They were most likely entrusted with the artistic side of the procession. They were all artists in the traditional manner, and likely to make equally traditional choices. They may only have been familiar in Greece with popular festivities and not 'urban' ones, as the representatives of the ruling class who organised those festivals imagined them to be, at least one such representation in a pure classicizing spirit had already taken place in Greece.
On 17 May 1824 the opening ceremony of the Ionian Academy took place in Corfu. All the teaching staff and other functionaries in this institution appeared in tunics and cloaks designed by the famous sculptor Pavlos Prosalentis 'in a manner entirely faithful to what we see in the beautiful remains of antiquity ${ }^{34}$ (fig. 5). If this classicizing performance with its references to antiquity is entirely understandable in 1824 under the influence of the Enlightenment, such awkward late classicism and the ancestor worship it entailed cannot be taken seriously in Athens of the thirties. Within the framework of national ideology, however, it served a specific purpose: to associate the present with the ancient past, as Damvergis himself clearly describes in the following passage:

'The Central Committee for the Centenary Celebrations, in organizing the festival to celebrate the hundredth anniversary of the Greek flag being raised once again on the Acropolis, was aiming on the one hand to give public expression to the emotions of honour, love and respect for the sacred symbol and on the other to connect the national present with Greek history through the ages. It considered that the waving flag fluttering above this holy rock would represent both a symbolic link between different eras in Greek history, and more especially connect the grandeur of Antiquity with the struggles of the War of Independence and with the present indomitable vitality of our race and the Greek destiny. ${ }^{35}$

The organizers, all proponents of the 'Great Idea', felt a constant need to stress the invincible nature of the Greek race because the festivities were being held in the wake of the collapse of the Greek irredentist dream and the ensuing problems relating to the refugees, such as housing, then as yet unresolved. Thus, through the rhetoric of the Centenary Celebration we can follow the redefining of the 'Great Idea'. Alexandros Zaimis, President of the Republic and chairman of the CCC, offers a typical example. During the inauguration ceremony for the Panhellenic War Memorial at Pedion Areos (the park's name being the Hellenized version of Campus Martius) on $30 \mathrm{March}$ 1930, he formulated a definition for a new 'Great Idea' based on the triad 'Homeland - Religion - Family', an ideal that Damvergis had been promoting in the columns of the newspaper Patria, published between 1902 and 1916. More specifically, Zaimis stressed: '[...] the Great 

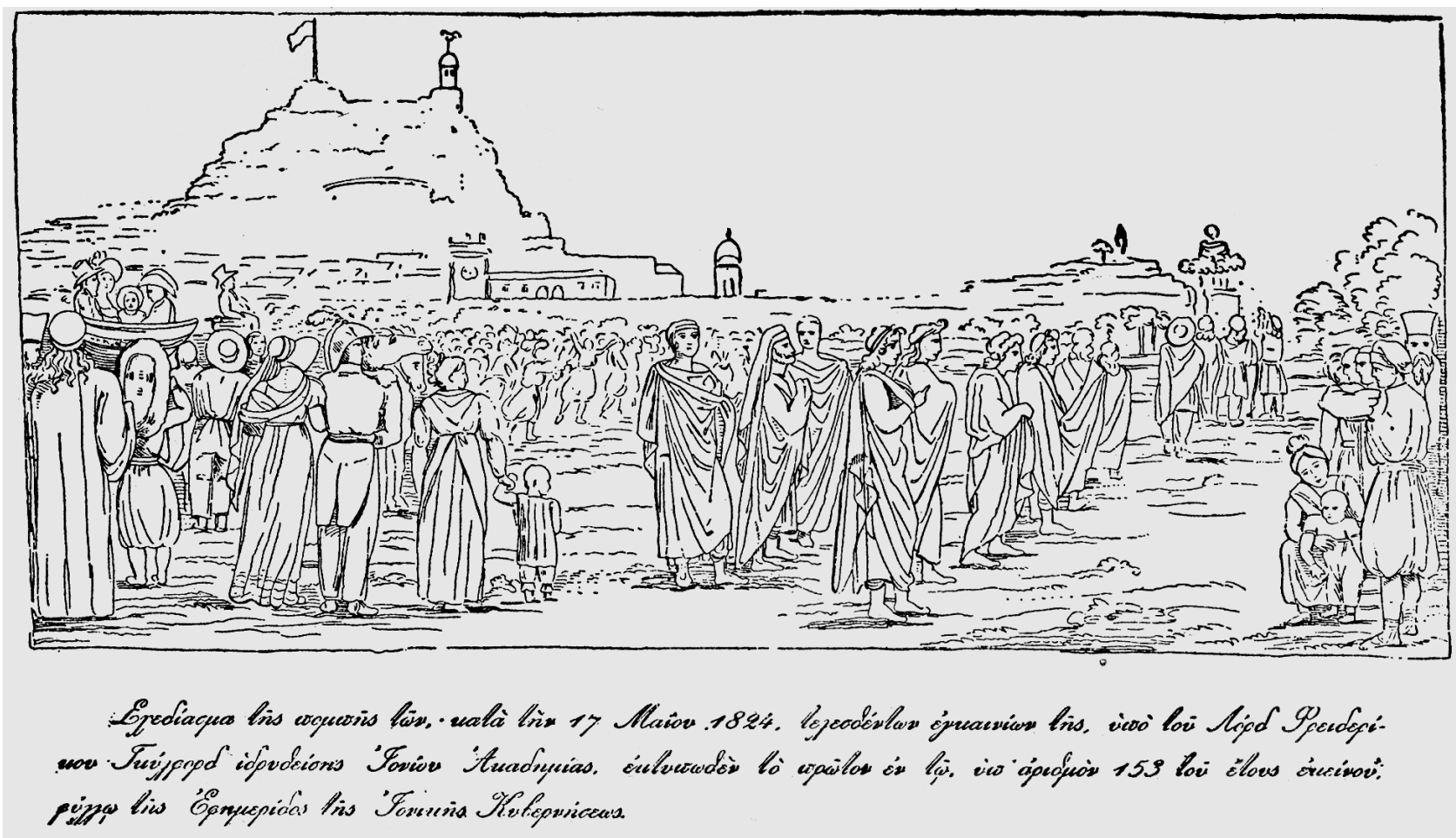

Fig. 5. Pavlos Prossalentis, Sketch of the procession for the opening ceremony of the Ionian Academy, 1924 (source: Typaldos-Iakovatos 1982, back cover).

Idea comprises respect for religion, love of the homeland and devotion to the family [...]'.36

From this point of view, the commemorations which were basically addressed to the people, gave the ruling class the opportunity to get across topical issues.

Returning to the archaeologists, who ensured the 'Greekness' of the commemorations, I will briefly mention a few memorials inspired by them. Two typical examples are the war memorials in Samos and Herakleion, both of which I have described at length elsewhere. ${ }^{37}$ Here I shall confine myself to a few comments which coincide with the point of view I am taking in this paper.

The Samos memorial is the work of a famous but mediocre artist called Ioannis Koulouris. It is an exact copy of the Chaeroneia Lion (fig. 6), and was expressly dedicated 'To the warriors of 1821' and not exclusively to the Samiot fighters. The choice of subject was made by Greek archaeologists and the Frenchman Guilleron, who had been approached by a representative of the Samiots. Georgios Oikonomos supervised the progress of the work. The memorial caused diverse reactions and divided the Samiot public into 'friends' and 'enemies of the lion'. Local controversies are of more general interest when they touch on the problem of public monuments in Greece and because, as can be seen from two newspapers representing the opposing sides, the pro-memorial Samos and the anti-memorial Aigaion which opened up a dialogue on what a war memorial should look like. The supporters of the memorial who had archaeologists such as Antonios Keramopoulos, Petros Kastriotis and the sculptor Antonios Sohos on their side, believed that it should take a symbolic form. On the other side, those who were against the memorial preferred busts and statues, because according to them, a memorial in symbolic form is 'the product of the imagination of highly literate people but not of the illiterate'.

Those views correspond to the two sides of the same conservative tendency concerning the art of official monuments and especially memorials. The point of view of those 'against the lion' indicates an individualism found mainly in what is basically bourgeois modern Greek art. 

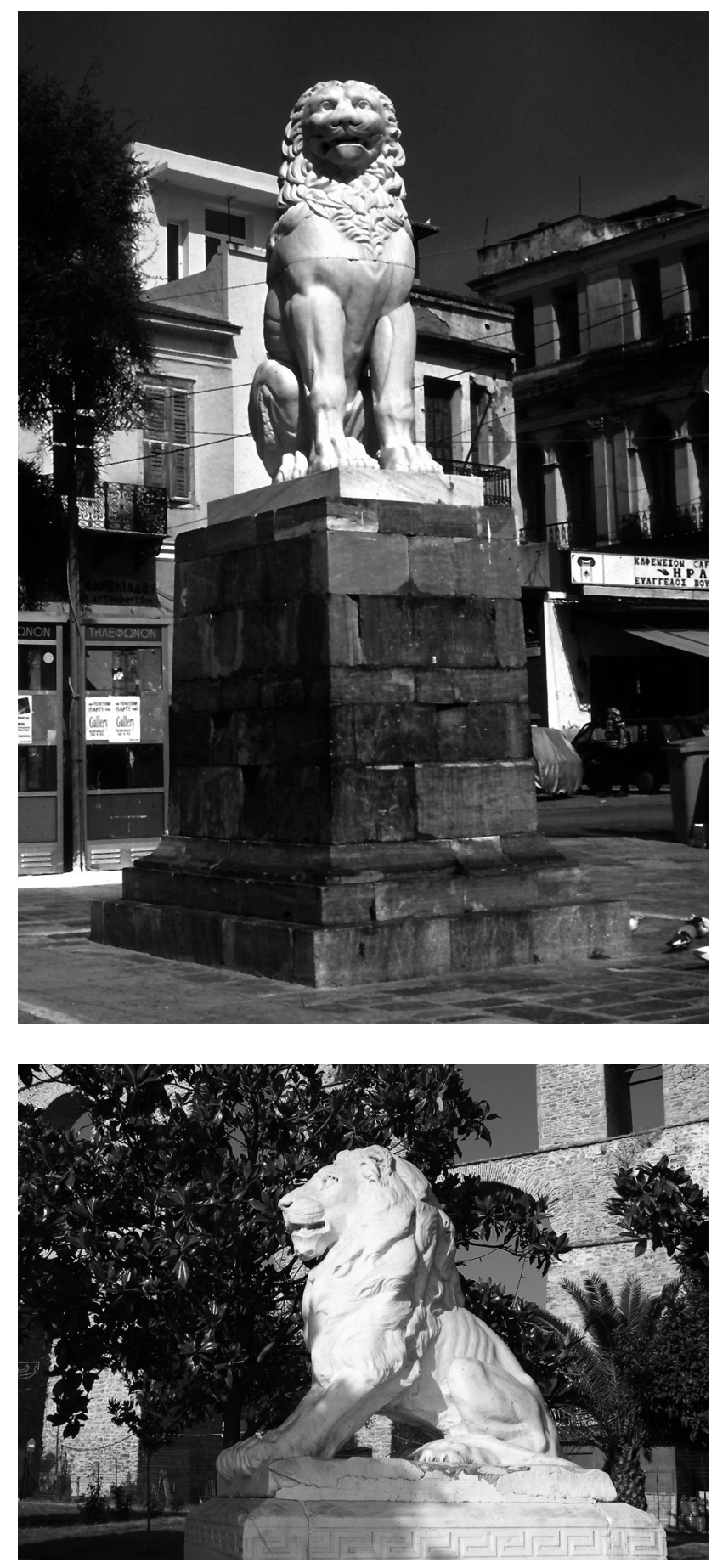

Fig. 6. Ioannis Koulouris, Samos War Memorial in Vathy, h. ca. 5.25 m., 1930.

Fig. 7. Ioannis Koulouris, Kavala War Memorial, 1930.
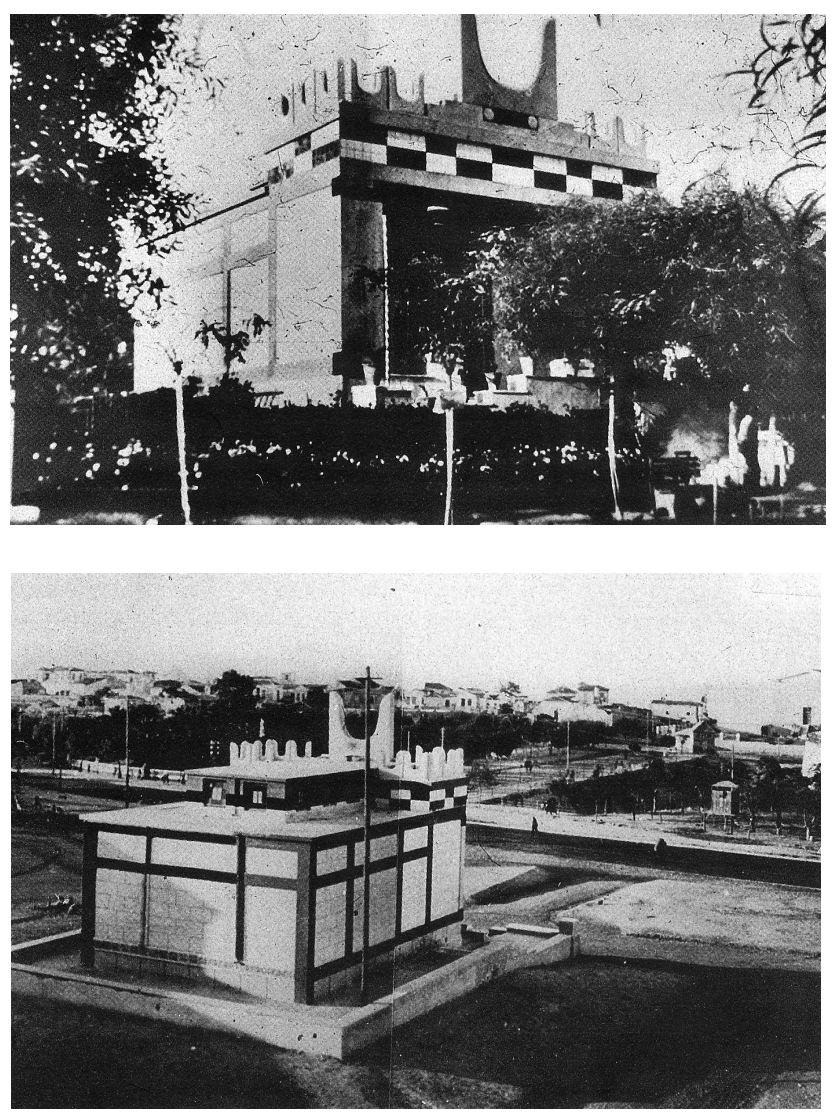

Fig. 8. Dimitrios Kyriakos, Herakleion War Memorial (façade), 10 x 12 m., on Eleftherias Sq., 1930 (source: vintage post card, Archive of Nikos Skoutelis).

Fig. 9. Dimitrios Kyriakos, Herakleion War Memorial (back) (source: vintage post card, Archive of Nikos Skoutelis).

Furthermore, it conceals a personality cult in the ancient tradition of busts and statues, which have tended to be the most common monuments from the nineteenth century to the present day. They were also part of the Greek fixation with honouring only the dead. Angelos Prokopiou talked about modern Greece's 'necrophilia', which had as a result that no true sculptural compositions were erected in the open air in Greece prior to $1956 .^{38}$

On the other hand, although the view of those who preferred the symbolic memorial was also quite old, it was more progressive, because it is harder to express an abstract idea and it demands maturity both on the part of the artist and of the public. The lion as a symbolic image was indeed not unknown to the Greek public, as there 


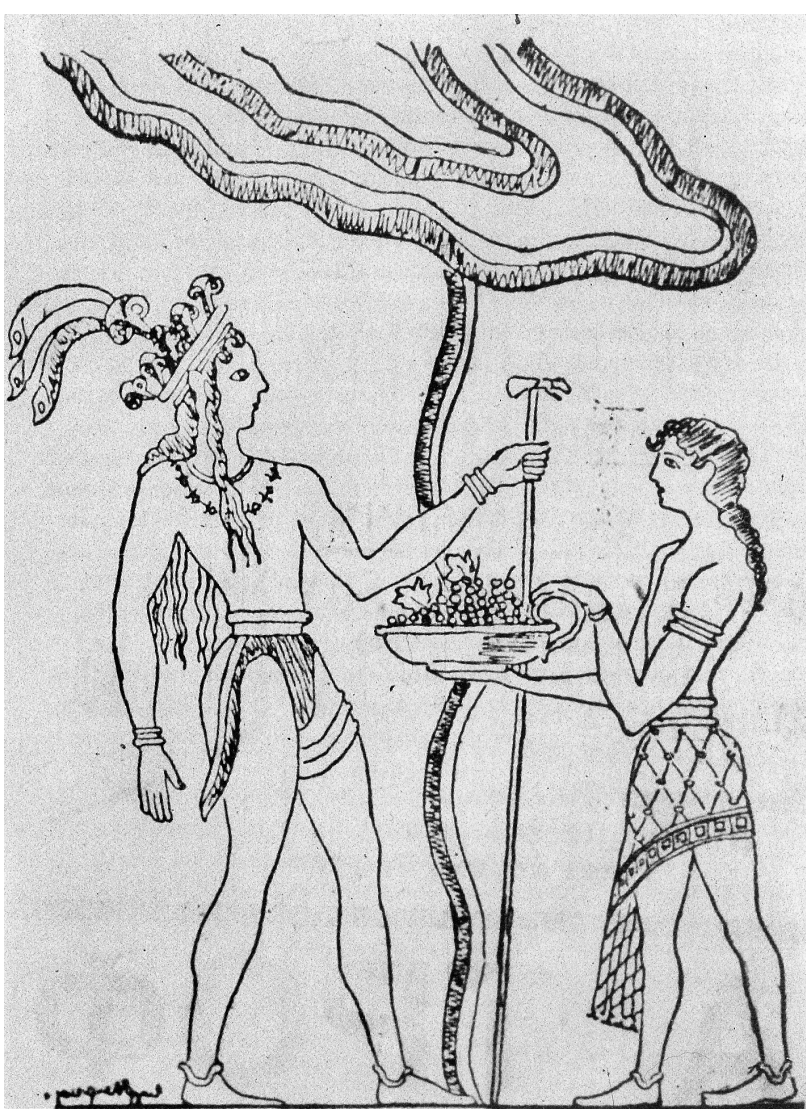

Fig. 10. Evangelos Markoyiannakis, 'Minoan Art' drawing for a label for exported grapes (source: Elefthera Skepsis 13 April 1930).

were other similar monuments on Greek soil. The same sculptor had produced another copy of the Chaeroneia Lion for the war memorial at Kavala (fig. 7). Yet another lion existed in the war memorial of Karystos and another was planned for an unspecified site in Macedonia but never realized. Apart from the political reasons which inspired such a negative reaction to this memorial - all those against it belonged to the anti-Venizelist opposition - we should take into account the change in public taste which was no longer satisfied with replicas of ancient works of art. And that was an aspect of the affair which the archaeologists had not bargained for.

The memorial in Herakleion is another monument inspired by archaeology, which incorporates Minoan architectural elements such as the red pillars on its façade and the double horns (figs 8-9). Spyridon Marinatos, who managed to convince the local committee to erect a monument in the 'Minoan style', was more ambitious about the universality of Minoan art, as a report from the local committee makes plain: 'On the recommendation of the Museum's Director Mr Marinatos, it has been decided that this monument shall be created in the Minoan style, which corresponds wonderfully to the idea of the eternal nature of undying virtue as well as to the need for Herakleion to be the first town to revive an architectural style which thanks to the wise and enchanting reconstructions by $\mathrm{Mr}$ Evans could become popular throughout the world. ${ }^{39}$ In the words of this romantically inclined young archaeologist, we can detect an ambition to see Minoan art taken up worldwide, a vain hope of course, since the development of art in the twentieth century was in no position to exercise such influences on popular taste, and Greece itself was even less qualified to do so. These ambitions were definitely an anachronism in the art of the inter-war years.

The memorial in Herakleion did not cause any adverse reactions, maybe because Cretans were for the most part supporters of Venizelos and so there was little opposition. Mainly, though, because Marinatos had paved the way with a number of lectures aiming 'to point out how the motifs of Minoan art in particular could be used in contemporary architecture, and in decorative arts and crafts. Despite the fact that Minoan art - more than any other art - comes the closest to the soul of contemporary art, is completely ignored. And this closeness is due to the fact that Minoan monuments have been fortunately confined to their narrow localities. ${ }^{30}$ How did Marinatos come up with the idea that Minoan art is very close to the soul of contemporary art? It is impossible to answer that. We can only assume that he had understood nothing of the changes that the twentieth century and Modernism had brought about. But what of it? He had already convinced his audience that Minoan art could be applied in modern life, judging from a 'Minoan-esque' sketch by a local artist named Evangelos Markoyiannakis (fig. 10), of which he said: 'the artist has entirely succeeded.'11 This sketch was intended to serve as a label for exported grapes.

In examining the Centenary Celebrations one has the feeling that the organizers could not see 'the spectre of an era about to begin', to use once more a phrase by Theotokas, ${ }^{42}$ and that they were facing the future by looking at the past. The excessive amounts of marble that were used to erect all these war memorials did not leave behind even one true work of art since their artists' imagination was exhausted in copying and imposing an outdated late 


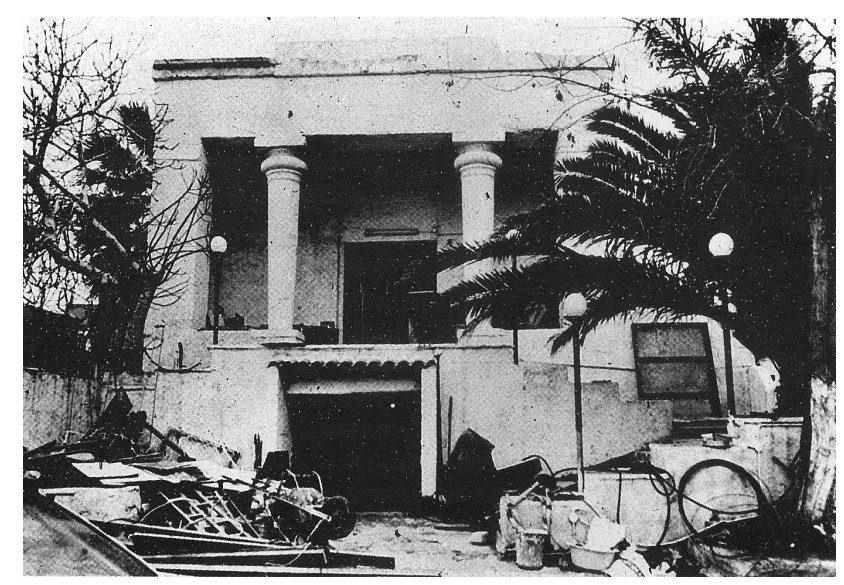

Fig. 11. Dimitrios Kyriakos, Herakleion War Memorial (present state).

classicism, while the generation of the thirties was already standing by in the wings. Despite the fact that few of its representatives were conservative, this group of artists wanted an art which not only came out of all periods of Greek history, but would also stand alongside European art, given that Modernism was now well established. Voices like those of Konstantinos Parthenis, who as a member of the panhellenic war memorial Committee expressed the view that 'the memorial should be the expression of its time', ${ }^{43}$ were drowned out by those of, for example, Anastasios Metaxas, who believed that 'the memorial should display the ancient lines'.

As far as the Centenary is concerned, the conflict between the conservative and modernizing tendencies that characterized the Greek inter-war period, ended in a victory for the former. Moreover the organizers were optimistic that the memorials would speak to the subsequent generations. They were unaware of the views of the likes of Kandinsky, who believed that the work of art which is not a child of its time is like a stillborn baby. ${ }^{44}$ They were also deluded into thinking that the crowds of people participating in the Athenian and local commemorations showed that they had got their message across to the populace.

The state of the war memorial in Herakleion on the very day after its inauguration, when it was found to have suffered serious damage and the image of its guard, slouching on the model of King Minos' throne, eating pumpkin seeds as well as the way it has been abused since, all speak volumes (fig. 11). One could dismiss the commemorations as spectacles meant for public consumption or as affairs that were appallingly kitsch. But, in examining the archival material available on the Centenary, one realizes that the whole state apparatus had been involved during a very critical period for the country.

The only thing that they succeeded in doing was perhaps to train organizers for this sort of activities. One is reminded of the celebrations that Georgios Oikonomos organized in 1937 for the centenary of the Archaeological Society which closely resembled the Celebration of the Flag described here. ${ }^{45}$ The CCC was a political force and the special committees collected the great minds of Greek society but, above all, archaeologists. This political force tried to impose ceremonies and memorials in accordance with a national ideology which they themselves believed in; to impose from on high an art which ignored reality.

Thus, despite the hopes that the Centenary created for the strengthening of modern Greek art, it is difficult today to find a work of sculpture from this project which is worthy of listing in the canon of modern Greek sculpture. Dionysios Kokkinos thought that the Centenary would constitute an 'account' of our national progress, ${ }^{46}$ but in the end it was reduced to empty rhetoric reserved for domestic consumption. Critics such as a journalist writing under the penname 'Eirene the Athenean', pointed out the sterile character of the events: 'All these commemorations dedicated to the Centenary will eventually be over, without leaving behind any sign of their passing. There are many, though, who will become rich through them, and only the memory of our liberators will remain destitute and sinned against'. ${ }^{47}$ The Greekness that had been sought in the fossilized forms of the past could not bring new life to Greek art unless we accept that it did so in a negative way. If, for example, we take Theotokas' criticism of modern Greek literature to have sprung from his reaction to the rhetoric of the Centenary.
Dora F. Markatou
Department of History and Archaeology
University of Ioannina
theodmarkat@yahoo.gr 


\section{Notes}

1. For the panhellenic war memorial and the involvement of Kapodistrias, see Markatou 1995, 37-68.

2. As stated in his last orders issued at Rimnikon on 8 June 1821; Kokkinos 1956, 148.

3. Orders issued by Alexandros Hypsilantis on 24 February 1821; Kokkinos 1956, 104.

4. Lambros 1911, 17.

5. Lambros 1911, 17.

6. Lambros 1916, 239.

7. Further on the CCC, see Markatou 1996, 27-52.

8. Haritakis $1921,8$.

9. Haritakis $1921,3$.

10. The term 'Greekness' (hellenikoteta) in its modern meaning was introduced by Kontantinos Pop in 1851. On Hellenicity, see Tziovas 1989.

11. See Skopetea 1988, 190-217.

12. Margaritis 2001, 152-73.

13. The Philhellenes' contribution to the War of Independence is shown in the eighth decree of the Fourth National Assembly, where Kapodistrias stresses that monuments must be erected in their honour.

14. Lambros 1911, 100-1.

15. Markatou 1996, esp. 28-42.

16. Cf. Janson 1985, 69-70; Le Normand-Romain 2006, 847; 860-63; 884-85.

17. Haritakis $1921,3$.

18. Lambros 1881, 67-69.

19. Haritakis 1921, 11.

20. Mittig 1985, esp. 64-67.

21. Kalpaxis 1990, 13.

22. The speech was delivered on 17 May 1930. See State General Archives (Г.A.K.) K301, F(older) 50 /Sub-Folder 4.

23. SGA (Г.A.K.), K301, F 50/SF 4.

24. SGA (Г.A.K.), K301, F 70, p. 302.
25. SGA (Г.А.К.), K301, F 70, p. 185.

26. SGA (Г.A.K.), K301, F 53/SF 1. On the schedule, see Estia, 25 April 1930, 5.

27. Eleftheron Vima, 20 May 1929, SGA (Г.А.К.), K301, F $53 /$ SF 1

28. Markatou 1996, 25.

29. Markatou 1996, 24.

30. Markatou 1996, 107. A letter from Ioannis Damvergis to Panos Aravantinos can be found at SGA (Г.A.K.), K301, F 73/SF 1 (dated 24 February 1930).

31. Markatou 1996, 28.

32. A telegram and letter of his from Berlin can be found at SGA (Г.A.K.), K301, F 76/SF 1 (dated 5 March 1930).

33. Markatou 1996, 41.

34. Typaldos-Iakovatos 1982, 25-26; 155.

35. SGA (Г.А.К.), K301, F70, 302.

36. Estia, 30 March 1930, 6.

37. Markatou 1998, 299-327.

38. Reference to the Monument to Labour, a work of art by Kostas Klouvatos that was erected at Analipseos Sq. in the Athenian suburb of Vironas, and was destroyed during the dictatorship of 1967-1974.

39. SGA (Г.A.K.), K301, F 61/SF 11.

40. Elefthera Skepsis 461 (18 February 1930) 1.

41. Elefthera Skepsis 506 (13 April 1930) 1.

42. Theotokas 1988, 24.

43. SGA (Г.A.K.), K301, F70.

44. Kandinsky 1952, 21.

45. Petrakos 1987, 195-203.

46. Haritakis 1921, 10.

47. Estia, 5 May 1930, 4. In order to boost their proceeds, some restaurant owners were offering the 'Centenary Dish', Estia, 12 April 1930, 1. 


\section{REFERENCES}

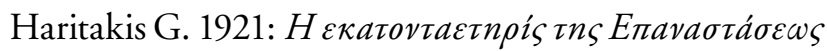
(Athens).

Janson H.W. 1985: 19th Century Sculpture(New York).

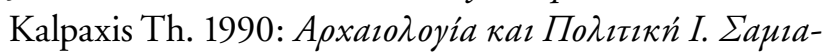

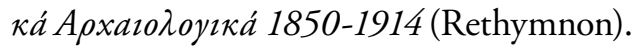

Kandinsky W. 1952: Über das Geistige in der Kunst (10th edition; Bern).

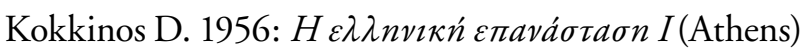

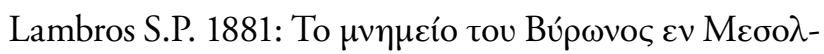

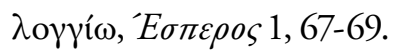

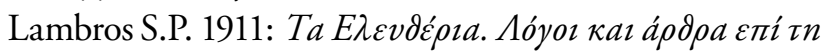

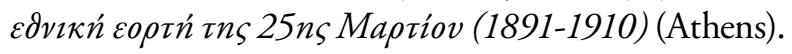

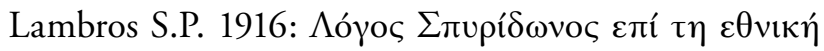

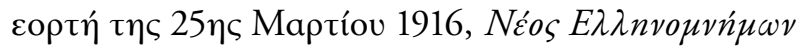
13 I (31-3-1916) 239.

Le Normand-Romain A. 2006: Der Klassizismus, in: Duby G. \& Daval J.-L. (eds), Sculpture. Von der Rennaissance bis zur Gegenwart (Cologne).

Margaritis G. 2001: Griechenland Wiedergeburt aus dem Geist der Antike, in: Flanke M. (ed.), Mythen der Nationen (2nd ed.; Munich-Berlin) 152-73.

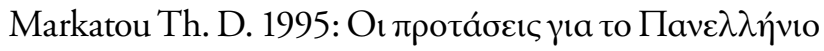

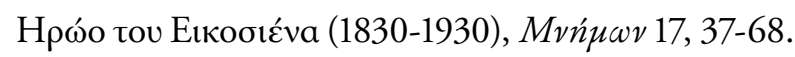

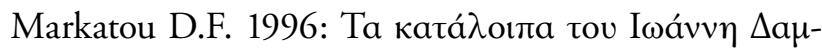

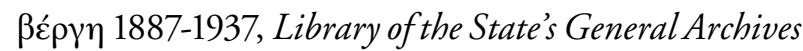
30 (Athens).

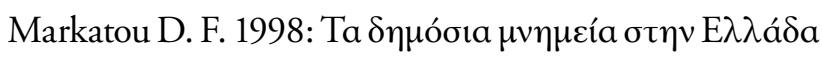

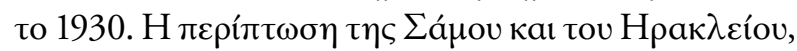

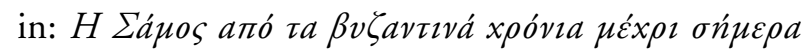
(Athens).

Mittig H.-E. 1985: Das Denkmal, in: Funkkollegkunst. Studienbegleitbrief 8 (Weinheim and Basel).

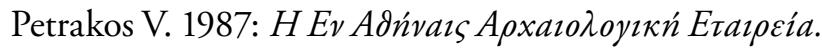

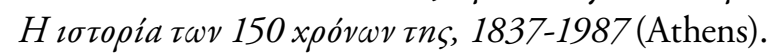

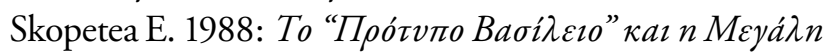

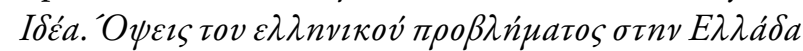
(1830-1880) (Athens).

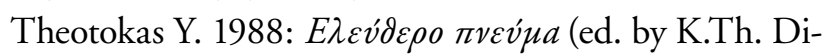
maras; Athens).

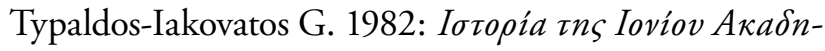
jias (ed. by S. Asdrahas; Athens).

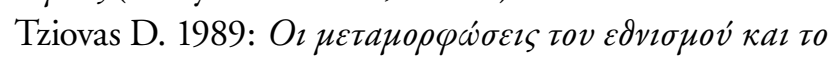

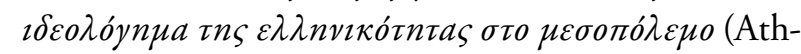
ens). 